\title{
Calcium intake and breast cancer risk: meta-analysis of prospective cohort studies
}

\author{
Khemayanto Hidayat ${ }^{1,2} \dagger$, Guo-Chong Chen ${ }^{1} \dagger$, Ru Zhang ${ }^{1}$, Xuan $\mathrm{Du}^{2}$, Sheng-Yi Zou ${ }^{2}$, Bi-Min Shi ${ }^{2 *}$ and \\ Li-Qiang Qin ${ }^{1,3 *}$ \\ ${ }^{1}$ Department of Nutrition and Food Hygiene, School of Public Health, Soochow University, Suzhou 215123, People's Republic of China \\ ${ }^{2}$ Department of Endocrinology and Metabolism, the First Affiliated Hospital of Soochow University, Suzhou 215123, People's Republic \\ of China \\ ${ }^{3}$ Jiangsu Key Laboratory of Preventive and Translational Medicine for Geriatric Disease, Soochow University, Suzhou 215123, \\ People's Republic of China
}

(Submitted 10 December 2015 - Final revision received 1 April 2016 - Accepted 2 April 2016 - First published online 12 May 2016)

\section{Abstract}

Findings from observational studies have suggested a possible relation between $\mathrm{Ca}$ and breast cancer risk. However, the results of these studies are inconclusive, and the dose-response relationship between $\mathrm{Ca}$ intake and risk of breast cancer remains to be determined. A meta-analysis of prospective studies was conducted to address these issues. PubMed and Embase databases were searched for relevant studies concerning the association between Ca intake and breast cancer up to March 2016. The summary relative risks (RR) with $95 \%$ CI were calculated with a random-effects model. The final analysis included eleven prospective cohort studies involving 26606 cases and 872895 participants. The overall RR of breast cancer for high $v$. low intake of Ca was 0.92 (95\% CI 0.85, 0.99), with moderate heterogeneity $\left(P=0.026, I^{2}=44 \cdot 2 \%\right)$. In the subgroup analysis, the inverse association appeared stronger for premenopausal breast cancer (RR $0.75 ; 95 \%$ CI $0.59,0.96$ ) than for postmenopausal breast cancer (RR 0.94; $95 \%$ CI 0.87, 1.01). Dose-response analysis revealed that each $300 \mathrm{mg} / \mathrm{d}$ increase in Ca intake was associated with $2 \%$ (RR $0.98 ; 95 \%$ CI 0.96, 0.99), $8 \%$ (RR 0.92; $95 \% \mathrm{CI} 0 \cdot 87,0.98$ ) and $2 \%$ (RR 0.98; $95 \% \mathrm{CI} 0 \cdot 97,0.99$ ) reduction in the risk of total, premenopausal and postmenopausal breast cancer, respectively. Our findings suggest an inverse dose-response association between Ca intake and risk of breast cancer.

Key words: Breast cancer: Calcium: Dose-response associations: Meta-analyses

Globally, breast cancer ranks first for cancer incidence and fifth for cancer mortality in women ${ }^{(1)}$. Dietary and lifestyle factors may have an important role in the development of breast cancer $^{(2-4)}$, among which $\mathrm{Ca}$ intake has been suggested as a potential protective factor in mounting experimental research $^{(5-10)}$ and several observational studies ${ }^{(11-13)}$. A metaanalysis by Chen et $a l .^{(14)}$ involving six prospective cohorts and nine case-control studies suggested a significant inverse association between $\mathrm{Ca}$ intake and risk of breast cancer, with a summary relative risk (RR) of $0.81(95 \% \mathrm{CI} 0.72,0.90)$ for the highest compared with the lowest intake of $\mathrm{Ca}$, with a significant publication bias. Their results became statistically non-significant after correcting for publication bias. The meta-analysis was followed by several subsequent prospective studies ${ }^{(15-19)}$ that also focused on the same topic, but their findings continued to be inconsistent. To clarify the association between $\mathrm{Ca}$ intake and risk of breast cancer, we performed an updated meta-analysis of prospective studies. Given the fact that high amounts of $\mathrm{Ca}$, particularly from supplements, might increase risks of certain diseases, such as $\mathrm{CVD}^{(20-24)}$ and kidney stones $^{(25,26)}$, we also attempted to explore the shape of the doseresponse association between $\mathrm{Ca}$ intake and breast cancer that has not been investigated in the previous meta-analysis.

\section{Methods}

\section{Search strategy}

This meta-analysis was planned, conducted and reported according to the Preferred Reporting Items for Systematic Reviews and Meta-Analyses (PRISMA) recommendation ${ }^{(27)}$. PubMed and Embase databases were searched for studies assessing the association between Ca intake and breast cancer up to March 2016. The following search terms were used to retrieve the relevant literature in the databases: ('calcium' OR 'dairy products' OR 'dairy' OR 'milk' OR 'cheese' OR 'yogurt' OR 'butter' OR 'cream') AND ('breast cancer' OR 'mammary gland cancer' OR 'breast neoplasms' OR 'mammary gland neoplasms' OR 'neoplasm of the breast' OR

Abbreviation: ER, oestrogen receptor; PR, progesterone receptor; RR, relative risk.

* Corresponding author: L.-Q. Qin, email qinliqiang@suda.edu.cn; B.-M. Shi, email shibimin@163.com

$\dagger$ These authors contributed equally to this work. 
'neoplasm of the mammary gland') AND ('cohort' OR 'prospective' OR 'nested case-control' OR 'case-cohort' OR 'observational study'). The search strategy had no language, publication date or publication type restriction. In addition, the reference lists of retrieved full publications and previous meta-analysis were reviewed to complement the search and to identify relevant studies that were missed during electronic database search. We also contacted the authors of the primary studies for further information.

\section{Study selection}

To be included in this meta-analysis, the studies had to meet the following inclusion criteria: (a) the study design was a prospective study (including a prospective cohort study, nested case-control study and a case-cohort study); (b) the exposure of interest was $\mathrm{Ca}$ intake (dietary and/or supplemental $\mathrm{Ca}$ ); (c) the outcome of interest was breast cancer incidence; (d) female participants; and (e) risk estimates with corresponding 95\% CI were available. Accordingly, retrospective studies, or studies on breast cancer mortality or recurrence, were excluded. If one study was reported in overlapping publications, the publication containing more detailed information (i.e. reporting data for subgroup or dose-response analyses) was selected.

\section{Data extraction and quality assessment}

Using a standardised data-collection form, the following data were abstracted from each study: the first author's last name, publication year, study population, duration of the study, country, length of follow-up, number of cases, dietary assessment method, sources of Ca intake (diet and/or supplement), the multivariable-adjusted risk estimates with their corresponding $95 \%$ CI for each category of Ca intake and statistical adjustment for potential confounding factors. The study quality was assessed using the nine-star Newcastle-Ottawa Scale $(\mathrm{NOS})^{(28)}$, in which each study was judged based on the selection of the study groups, the comparability of the groups and the ascertainment of exposure and outcome. Two investigators (K. H. and G.-C. C.) participated in literature search, study selection and data extraction independently. Any discrepancies regarding inclusion were solved through group discussion.

\section{Statistical analysis}

RR was chosen as the common measure of association across this study, and hazard ratio was directly considered as RR. A DerSimonian \& Laird random-effects model $^{(29)}$ was used to calculate the summary risk estimates. The degree of heterogeneity in the relationship between $\mathrm{Ca}$ intake and breast cancer across studies was assessed using $Q$ and $I^{2}$ statistics. For the $Q$ statistic, $P<0 \cdot 1$ was considered statistically significant, and for the $I^{2}$ statistic the following conventional cut-off points were used: $<25 \%$ (low heterogeneity), 25-50\% (moderate heterogeneity) and $>75 \%$ (severe heterogeneity). Both Begg's rank correlation test and Egger's linear regression test were performed to investigate potential publication bias ${ }^{(30)}$.
If evidence of publication bias was observed, the trim and fill method was applied to correct the bias ${ }^{(31)}$.

To explore potential sources of heterogeneity, subgroup and meta-regression analyses were performed according to geographic region, duration of follow-up, sources of $\mathrm{Ca}$, menopausal status and quality scores. To investigate the impacts of individual studies on the overall results, we also performed a sensitivity analysis by omitting one study in each turn while pooling results from the remainder. We performed a linear dose-response analysis examining the association between $\mathrm{Ca}$ intake and breast cancer risk according to the method proposed by Greenland \& Longnecker ${ }^{(32)}$ and Orsini et al. ${ }^{(33)}$. This method requires the number of cases and personyears and the risk estimates with their variance estimates for at least three quantitative exposure categories. For the studies that did not provide the number of cases and/or person-years in each exposure category, we estimated these data from the total number of cases and person-years. For each study, the median or mean level of intake for each category was assigned to each corresponding risk estimate. When the median or mean intake per category was not provided, we considered the midpoint of the upper and lower boundaries in each category as average intake. If the highest or lowest category was open-ended, we assumed the width of the interval to be the same as in the closest category. Forest plots of the linear dose-response meta-analysis were presented for RR for each $300 \mathrm{mg} / \mathrm{d}$ increment of $\mathrm{Ca}$ intake (the unit equivalent to $\mathrm{Ca}$ content in $250 \mathrm{ml}$ or one serving of milk). Potential non-linear doseresponse relationship between $\mathrm{Ca}$ intake and breast cancer risk was examined by modelling exposure levels using restricted cubic splines with three knots at percentiles 10, 50 and $90 \%$ of the whole Ca distribution ${ }^{(34)}$. The $P$ value for non-linearity was calculated by testing the null hypothesis that the coefficient of the second spline is equal to 0 . All statistical analyses were performed using the STATA software, version 11.0 (StataCorp. LP). All $P$ values were two-sided, and the level of significance was at $<0 \cdot 05$, unless explicitly stated.

\section{Results}

\section{Study characteristics}

A flow chart of study selection, including reasons for exclusion, is presented in Fig. 1. We included eleven studies ${ }^{(11-13,15-19,35-37)}$ that fully met our inclusion criteria for this meta-analysis. The characteristics of the included studies are summarised in Table 1 . These studies were published between 2002 and 2013, with a total of 26606 breast cancer cases diagnosed among 872895 participants. Ten studies were conducted in Western populations (five in the USA, one in Finland, one in France, one in Norway, one in Sweden and one in ten European countries), and one study consisted of Singaporean Chinese. The duration of follow-up ranged from 7 to 25 years. One study ${ }^{(36)}$ was conducted among postmenopausal women only, six studies ${ }^{(12,13,16,17,19,35)}$ reported results by menopausal status and four studies ${ }^{(11,15,18,37)}$ combined premenopausal and postmenopausal breast cancer. One study ${ }^{(37)}$ further reported results by oestrogen receptor (ER) and progesterone receptor 


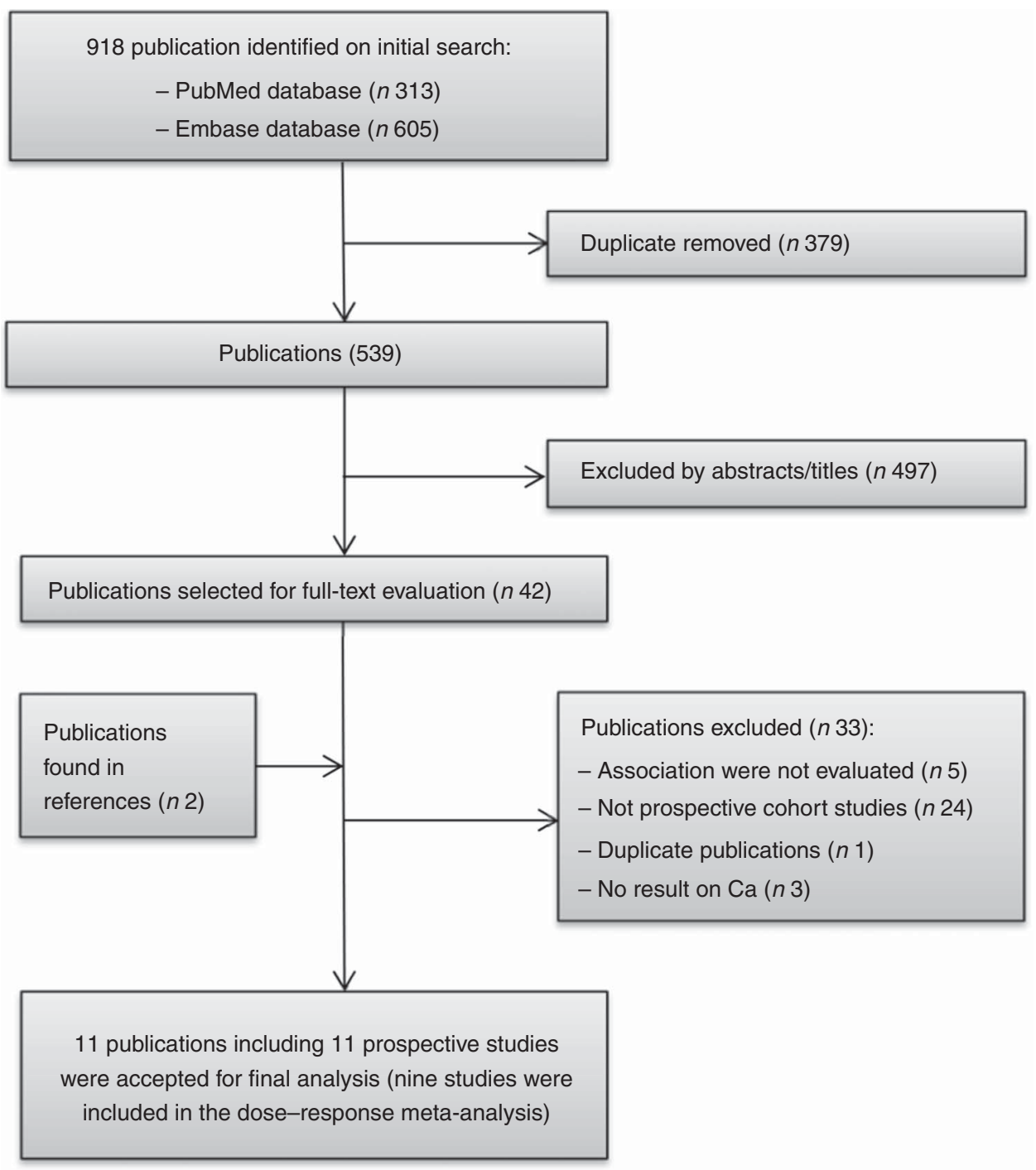

Fig. 1. Flow chart of study selection.

(PR) status of the tumour ${ }^{(37)}$. Either FFQ or 24-h recall was used as a dietary assessment tool. Ca intakes in the highest categories across studies ranged from $>345$ to $>1750 \mathrm{mg} / \mathrm{d}$, and the intakes in the lowest categories ranged from $<203.2$ to $<807 \mathrm{mg} / \mathrm{d}$. Most individual studies adjusted for a wide range of potential confounding factors, such as age, BMI, family history of breast cancer, hormone replacement therapy use and total energy intake. The details of quality assessment according to the nine-star NOS are presented in the online Supplementary Table S1. Nine of these studies were given scores of $\geq 7$.

\section{Calcium intake and breast cancer risk, high v. low intake}

The combined multivariable-adjusted $\mathrm{RR}$ for the highest $v$. lowest Ca intake was 0.92 (95\% CI 0.86, 0.99) (online Supplementary Fig. S1), with evidence of moderate heterogeneity $\left(P=0.026, I^{2}=44.2 \%\right)$. Both the Begg's rank correlation test and Egger's linear regression test suggested the presence of publication bias (Begg, $P=0.029$; Egger, $P=0.016$ ).
However, because no missing studies were detected to be filled, the results remained unchanged despite the fact that the trim and fill method was performed to correct the bias.

\section{Subgroup and sensitivity analyses}

The results of subgroup analyses stratified by geographic area, duration of follow-up, type of Ca intake, source of Ca, menopausal status and quality scores are presented in Table 2 . The inverse association between $\mathrm{Ca}$ intake and breast cancer risk was not significantly affected by these factors ( $P$ difference $>0 \cdot 130$ ). By menopausal status, the summary RR were 0.75 (95\% CI 0.59, 0.96) for premenopausal breast cancer and 0.94 (95\% CI $0 \cdot 87,1.01)$ for postmenopausal breast cancer. By sources of $\mathrm{Ca}$, the summary RR were 0.93 (95\% CI $0.84,1.03$ ) for total Ca, 0.90 (95\% CI 0.84, 0.97) for dietary Ca and 0.98 (95\% CI 0.92, 1.03) for supplemental Ca. Few studies ${ }^{(12,35)}$ also reported results for dairy $\mathrm{Ca}$ intake, and the summary $\mathrm{RR}$ were $0 \cdot 80(95 \%$ CI $0.53,1.21)$ for dairy Ca and 1.00 (95\% CI 0.78, 1.29) 


\section{N British Journal of Nutrition}

Table 1. Prospective cohort studies of calcium intake and breast cancer risk (Adjusted relative risks (RR) and $95 \%$ confidence intervals)

\begin{tabular}{|c|c|c|c|c|c|c|c|c|}
\hline $\begin{array}{l}\text { References } \\
\text { (country) }\end{array}$ & Study population & $\begin{array}{l}\text { Duration of } \\
\text { follow-up } \\
\text { (years) }\end{array}$ & $\begin{array}{l}\text { No. of } \\
\text { cases }\end{array}$ & $\begin{array}{l}\text { Dietary } \\
\text { assessment }\end{array}$ & Type of intake & Comparison & Adjusted RR $(95 \% \mathrm{Cl})$ & Adjustment \\
\hline $\begin{array}{l}\text { Knekt et al. } \\
\quad \text { (Finland) }\end{array}$ & $\begin{array}{l}4697 \text { women aged } \\
15-90 \text { years }\end{array}$ & 25 & 88 & Questionnaire & Dietary $\mathrm{Ca}$ & High $v$. low & $0.44(0.24,0.80)$ & $\begin{array}{l}\text { Age, total energy intake and other } \\
\text { potential confounding factors } \\
\text { Age, BMl, physical activity, history of } \\
\text { BBD, family history of breast cancer, } \\
\text { height change, age at menarche, } \\
\text { parity, age at first birth, alcohol intake, } \\
\text { total energy and fat intake, glycaemic } \\
\text { index value and intake of } \beta \text {-carotene, } \\
\text { alcohol, vitamin E }\end{array}$ \\
\hline \multirow[t]{5}{*}{$\begin{array}{l}\text { Shin et al. } \\
\quad(\text { USA })\end{array}$} & \multirow{5}{*}{$\begin{array}{l}88691 \text { women with a } \\
\text { mean age of } \\
46.7 \text { years }\end{array}$} & \multirow[t]{5}{*}{16} & \multirow[t]{5}{*}{3842} & \multirow[t]{5}{*}{$\mathrm{FFQ}$} & Total Ca & $>1250 \mathrm{v} . \leq 500 \mathrm{mg} / \mathrm{d}$ & $\begin{array}{l}\text { PRM: } 0.80(0.58,1.12) \\
\text { POM: } 0.93(0.77,1.12)\end{array}$ & \multirow{5}{*}{$\begin{array}{l}\text { Age, BMI, physical activity, history of } \\
\text { BBD, family history of breast cancer, } \\
\text { height change, age at menarche, } \\
\text { parity, age at first birth, alcohol intake, } \\
\text { total energy and fat intake, glycaemic } \\
\text { index value and intake of } \beta \text {-carotene, } \\
\text { alcohol, vitamin E }\end{array}$} \\
\hline & & & & & Dietary $\mathrm{Ca}$ & $>1000 \mathrm{v} . \leq 500 \mathrm{mg} / \mathrm{d}$ & $\begin{array}{l}\text { PRM: } 0.67(0.49,0.92) \\
\text { POM: } 0.99(0.81,1.21)\end{array}$ & \\
\hline & & & & & $\begin{array}{l}\text { Supplemental } \\
\quad \mathrm{Ca}\end{array}$ & $\geq 900 \mathrm{mg} / \mathrm{d} v$. non-user & $\begin{array}{l}\text { PRM: } 1.10(0.81,1.50) \\
\text { POM: } 0.93(0.81,1.08)\end{array}$ & \\
\hline & & & & & Dairy Ca & $>800 \mathrm{v} . \leq 200 \mathrm{mg} / \mathrm{d}$ & $\begin{array}{l}\text { PRM: } 0.69(0.48,0.98) \\
\text { POM: } 1.11(0.88,1.40)\end{array}$ & \\
\hline & & & & & Non-dairy Ca & $>600 v . \leq 200 \mathrm{mg} / \mathrm{d}$ & $\begin{array}{l}\text { PRM: } 1.28(0.91,1.80) \\
\text { POM: } 0.93(0.75,1.15)\end{array}$ & \\
\hline $\begin{array}{l}\text { McCullough } \\
\text { et al. }{ }^{(36)} \\
\text { (USA) }\end{array}$ & $\begin{array}{l}68567 \\
\text { postmenopausal } \\
\text { women aged } \\
50-74 \text { years }\end{array}$ & $7 \cdot 8$ & 2855 & FFQ & $\begin{array}{l}\text { Total Ca } \\
\text { Dietary Ca } \\
\text { Supplemental } \\
\quad \mathrm{Ca}\end{array}$ & $\begin{array}{l}>1750 \mathrm{v} . \leq 500 \mathrm{mg} / \mathrm{d} \\
>1250 \mathrm{v} . \leq 500 \mathrm{mg} / \mathrm{d} \\
>1000 \mathrm{v} . \leq 250 \mathrm{mg} / \mathrm{d}\end{array}$ & $\begin{array}{l}0.91(0.79,1.06) \\
0.80(0.67,0.95) \\
0.98(0.86,1.12)\end{array}$ & $\begin{array}{l}\text { Age, energy, history of breast cyst, } \\
\text { family history of breast cancer, race, } \\
\text { height, weight gain, alcohol intake, } \\
\text { age at first birth, parity, education, } \\
\text { mammography history, and HRT use }\end{array}$ \\
\hline \multirow[t]{4}{*}{$\begin{array}{l}\text { Kesse-Guyot } \\
\text { et al. }{ }^{(12)} \\
\text { (France) }\end{array}$} & \multirow[t]{4}{*}{$\begin{array}{l}3627 \text { women aged } \\
35-60 \text { years }\end{array}$} & \multirow[t]{4}{*}{$7 \cdot 7$} & \multirow[t]{4}{*}{92} & \multirow[t]{4}{*}{ 24-h recall } & Total $\mathrm{Ca}$ & $>1144$ v. $<807 \mathrm{mg} / \mathrm{d}$ & $\begin{array}{l}\text { All women: } 0.50(0.27,0.91) \\
\text { PRM: } 0.26(0.10,0.71) \\
\text { POM: } 0.76(0.34,1.70)\end{array}$ & \multirow{4}{*}{$\begin{array}{l}\text { Age, BMI, educational level, parity, } \\
\text { marital status, energy from fat and } \\
\text { other sources, alcohol intake, family } \\
\text { history of breast cancer, menopausal } \\
\text { status, smoking status, } \\
\text { supplementation, HRT use and } \\
\text { consumption of SFA, vegetable, meat }\end{array}$} \\
\hline & & & & & Dairy Ca & $>733 \mathrm{v} .<422 \mathrm{mg} / \mathrm{d}$ & $\begin{array}{l}\text { All women: } 0.58(0.32,1.04) \\
\text { PRM: } 0.32(0.12,0.82)\end{array}$ & \\
\hline & & & & & Non-dairy $\mathrm{Ca}$ & $>451 \mathrm{v} .<308 \mathrm{mg} / \mathrm{d}$ & $\begin{array}{l}\text { POM: } 0.87(0.40,1.92) \\
\text { All women: } 0.76(0.42,1.36) \\
\text { PRM: } 0.34,1.67)\end{array}$ & \\
\hline & & & & & & & POM: $0.84(0.35,1.98)$ & \\
\hline \multirow[t]{3}{*}{$\begin{array}{l}\text { Lin et al. }{ }^{(13)} \\
\quad(\text { USA) }\end{array}$} & \multirow{3}{*}{$\begin{array}{l}31487 \text { women aged } \\
\geq 45 \text { years }\end{array}$} & \multirow[t]{3}{*}{10} & \multirow[t]{3}{*}{1019} & \multirow[t]{3}{*}{ FFQ } & Total Ca & $\geq 1366 \mathrm{v} .<617 \mathrm{mg} / \mathrm{d}$ & $\begin{array}{l}\text { PRM: } 0.61(0.40,0.92) \\
\text { POM: } 1.17(0.92,1.50)\end{array}$ & \multirow{3}{*}{$\begin{array}{l}\text { Age, BMI, physical activity, family history } \\
\text { of breast cancer, history of benign } \\
\text { breast disease, age at menarche, age } \\
\text { at first birth, multivitamin, smoking, } \\
\text { alcohol, total energy intake, age at } \\
\text { menopause and baseline HRT use }\end{array}$} \\
\hline & & & & & Dietary $\mathrm{Ca}$ & $\geq 998 v .<557 \mathrm{mg} / \mathrm{d}$ & $\begin{array}{l}\text { PRM: } 0.84(0.57,1.22) \\
\text { POM: } 1.10(0.86,1.39)\end{array}$ & \\
\hline & & & & & $\begin{array}{l}\text { Supplemental } \\
\mathrm{Ca}\end{array}$ & $\geq 500 \mathrm{v.} .0 \mathrm{mg} / \mathrm{d}$ & $\begin{array}{l}\text { PRM: } 0.71(0.47,1.07) \\
\text { POM: } 1.05(0.86,1.30)\end{array}$ & \\
\hline \multirow{2}{*}{$\begin{array}{l}\text { Park et al. }{ }^{(15)} \\
\quad \text { (USA) }\end{array}$} & \multirow[t]{2}{*}{198903 women } & \multirow[t]{2}{*}{7} & \multirow[t]{2}{*}{5856} & \multirow[t]{2}{*}{ FFQ } & Total Ca & 1530 v. $526 \mathrm{mg} / \mathrm{d}$ & $0.98(0.90,1.07)$ & \multirow[b]{2}{*}{$\begin{array}{l}\text { Race/ethnicity, BMI, age at first birth, } \\
\text { number of children, age at } \\
\text { menopause, education, marital } \\
\text { status, family history of cancer, } \\
\text { physical activity, HRT use, smoking, } \\
\text { and intakes of red meat, alcohol, fat } \\
\text { and total energy }\end{array}$} \\
\hline & & & & & $\begin{array}{l}\text { Dietary Ca } \\
\text { Supplemental } \\
\quad \mathrm{Ca}\end{array}$ & $\begin{array}{l}1247 \text { v. } 478 \mathrm{mg} / \mathrm{d} \\
\geq 1000 \text { v. } 0 \mathrm{mg} / \mathrm{d}\end{array}$ & $\begin{array}{l}0.94(0.86,1.03) \\
0.98(0.91,1.06)\end{array}$ & \\
\hline $\begin{array}{l}\text { Larsson } \\
\quad \text { et al. } \\
\text { (Sweden) }\end{array}$ & 61433 women & $17 \cdot 4$ & 2952 & FFQ & Total $\mathrm{Ca}$ & $\geq 1125 \mathrm{v} .<727 \mathrm{mg} / \mathrm{d}$ & $\begin{array}{l}\text { Overall: } 0.97(0.87,1.09) \\
\text { ER+/PR }+ \text { tumours: } 1.01 \\
\quad(0.85,1.21) \\
\text { ER+/PR }- \text { tumours: } 0.97 \\
\quad(0.70,1.34) \\
\text { ER }-/ P R-\text { tumours: } 0.66 \\
\quad(0.44,0.99)\end{array}$ & $\begin{array}{l}\text { Age, education, BMI, height, parity, age } \\
\text { at first birth, age at menarche, age at } \\
\text { menopause, use of oral } \\
\text { contraceptives, use of } \\
\text { postmenopausal hormones, family } \\
\text { history of breast cancer, history of } \\
\text { benign breast disease and intakes of } \\
\text { alcohol, dietary fibre and total energy }\end{array}$ \\
\hline
\end{tabular}




\section{N British Journal of Nutrition}

\begin{tabular}{|c|c|c|c|c|c|c|c|c|}
\hline $\begin{array}{l}\text { References } \\
\text { (country) }\end{array}$ & Study population & $\begin{array}{l}\text { Duration of } \\
\text { follow-up } \\
\text { (years) }\end{array}$ & $\begin{array}{l}\text { No. of } \\
\text { cases }\end{array}$ & $\begin{array}{l}\text { Dietary } \\
\text { assessment }\end{array}$ & Type of intake & Comparison & Adjusted RR $(95 \%$ Cl) & Adjustment \\
\hline $\begin{array}{l}\text { Hjartåker } \\
\text { et al. }{ }^{(16)} \\
\text { (Norway) }\end{array}$ & 64904 women & 8.6 & 1407 & $\mathrm{FFQ}$ & Dietary $\mathrm{Ca}$ & $\geq 814.2$ v. $<552.6 \mathrm{mg} / \mathrm{d}$ & $\begin{array}{l}\text { PRM: } 0.65(0.39,1.08) \\
\text { POM: } 0.85(0.70,1.04)\end{array}$ & $\begin{array}{l}\text { Age, energy intake, alcohol intake, } \\
\text { height, weight increase since the age } \\
\text { of } 18 \text { years, level of physical activity, } \\
\text { years of education, maternal history } \\
\text { of breast cancer, mammography } \\
\text { practice, age at menarche, number of } \\
\text { children and age at first birth, and use } \\
\text { of oral contraceptives }\end{array}$ \\
\hline $\begin{array}{l}\mathrm{Li} \text { et al. }{ }^{(17)} \\
\quad \text { (Singapore) }\end{array}$ & $\begin{array}{l}35298 \text { women aged } \\
45-74 \text { years }\end{array}$ & $14 \cdot 2$ & 823 & $\mathrm{FFQ}$ & Total Ca & $>345$ v. $<203.2 \mathrm{mg} / \mathrm{d}$ & $\begin{array}{l}\text { PRM: } 0.87(0.59,1.28) \\
\text { POM: } 1.09(0.86,1.38)\end{array}$ & $\begin{array}{l}\text { Age, BMI, dialect group, interview year, } \\
\text { education, family history of breast } \\
\text { cancer, age when period become } \\
\text { regular and number of live births }\end{array}$ \\
\hline $\begin{array}{l}\text { Genkinger } \\
\text { et al. } \\
\text { (USA) }\end{array}$ & $\begin{array}{l}52062 \text { women aged } \\
21-69 \text { years }\end{array}$ & 12 & 1268 & $\mathrm{FFQ}$ & Dietary Ca & $\geq 1000 \mathrm{v} .<200 \mathrm{mg} / \mathrm{d}$ & $1.10(0.79,1.53)$ & $\begin{array}{l}\text { Energy intake, age at first menarche, } \\
\text { BMl, family history of breast cancer, } \\
\text { education, parity and age at first live } \\
\text { birth, oral contraceptive use, } \\
\text { menopausal status, age at } \\
\text { menopause, menopausal hormone } \\
\text { use, vigorous physical activity and } \\
\text { alcohol intake }\end{array}$ \\
\hline $\begin{array}{l}\text { Abbas et al. }{ }^{(19)} \\
\text { (ten } \\
\text { European } \\
\text { countries) }\end{array}$ & 319985 women & 8.8 & 7760 & Questionnaire & Dietary $\mathrm{Ca}$ & $\geq 1231$ v. $<635 \mathrm{mg} / \mathrm{d}$ & $\begin{array}{l}\text { All women: } 0.91(0.83,1.01) \\
\text { PRM: } 0.98(0.80,1.19) \\
\text { POM: } 0.90(0.79,1.02)\end{array}$ & $\begin{array}{l}\text { Age, centre, non-fat, non-alcohol } \\
\text { energy, fat, alcohol consumption, } \\
\text { weight, height, smoking status, } \\
\text { education level, menopausal status, } \\
\text { current use of contraceptives or } \\
\text { hormones, physical activity, age at } \\
\text { menarche }\end{array}$ \\
\hline
\end{tabular}

PRM, premenopausal women; POM ,postmenopausal women; BBD, benign breast disease; HRT, hormone replacement therapy; ER/PR, oestrogen and progesterone receptors. 
Table 2. Subgroup analysis of breast cancer in relation to calcium intake (Relative risks (RR) and $95 \%$ confidence intervals)

\begin{tabular}{|c|c|c|c|c|c|c|}
\hline Groups & No. of studies & $\mathrm{RR}$ & $95 \% \mathrm{Cl}$ & $P^{*}$ & $I^{2}(\%)$ & $P+$ \\
\hline Total & 11 & 0.93 & $0.87,0.99$ & 0.094 & 36 & \\
\hline \multicolumn{7}{|l|}{ Geographic area } \\
\hline North America & 5 & 0.95 & $0.86,1.04$ & $0 \cdot 136$ & $38 \cdot 4$ & \\
\hline Europe & 5 & 0.84 & $0.72,0.97$ & 0.027 & 60.5 & $0.409 \ddagger$ \\
\hline Asia & 1 & 1.03 & $0.84,1.25$ & 0.330 & 0 & $0.630 \ddagger$ \\
\hline \multicolumn{7}{|c|}{ Duration of follow-up (years) } \\
\hline$\geq 10$ & 7 & 0.93 & $0.84,1.03$ & 0.041 & $48 \cdot 6$ & 0.704 \\
\hline$<10$ & 4 & 0.88 & $0.77,1.00$ & 0.085 & $51 \cdot 1$ & \\
\hline \multicolumn{7}{|l|}{ Type of intake } \\
\hline Total & 6 & 0.93 & $0.84,1.03$ & 0.063 & $46 \cdot 1$ & \\
\hline Dietary & 9 & 0.90 & $0.84,0.97$ & 0.051 & 43.9 & $0.467 \S$ \\
\hline Supplemental & 4 & 0.98 & $0.92,1.03$ & 0.426 & 0 & $0.669 \S$ \\
\hline \multicolumn{7}{|l|}{ Source of $\mathrm{Ca}$} \\
\hline Dairy $\mathrm{Ca}$ & 2 & 0.80 & $0.53,1.21$ & 0.025 & $72 \cdot 8$ & 0.472 \\
\hline Non-dairy $\mathrm{Ca}$ & 2 & 1.00 & $0.78,1.29$ & 0.193 & $29 \cdot 1$ & \\
\hline \multicolumn{7}{|l|}{ Menopausal status } \\
\hline Premenopausal & 6 & 0.75 & $0.59,0.96$ & 0.048 & $55 \cdot 2$ & 0.130 \\
\hline Postmenopausal & 7 & 0.94 & $0.87,1.01$ & 0.373 & $7 \cdot 3$ & \\
\hline \multicolumn{7}{|l|}{ Quality scores } \\
\hline$\geq 7$ & 9 & 0.93 & $0.87,0.99$ & 0.094 & 36 & 0.805 \\
\hline$<7$ & 2 & 0.92 & $0.85,0.99$ & 0.009 & 85.4 & \\
\hline
\end{tabular}

* $P$ value for heterogeneity among studies.

† $P$ value for heterogeneity between groups according to meta-regression.

$\ddagger$ Studies conducted in the North America as a reference group.

$\S P$ Total $\mathrm{Ca}$ intake data as a reference group.

for non-dairy Ca. Results of the sensitivity analysis indicated that the overall risk estimates were not dominated by any single study, with summary RR ranging from 0.90 (95\% CI $0.83,0.98)$ to 0.93 (95\% CI $0.87,0.99$ ). The summary RR was 0.91 (95\% CI $0.84,0.98)$ after an exclusion of the only Asian study. In addition, one study ${ }^{(37)}$ reported results by ER and PR status of the tumour, and the inverse association of $\mathrm{Ca}$ intake with breast cancer risk appeared to be restricted to women with ER-negative and PRnegative tumours (RR 0.66; $95 \%$ CI 0.44, 0.99).

\section{Dose-response analysis}

Two studies ${ }^{(11,18)}$ that did not report sufficient data for the dose-response analysis were excluded, and the remaining nine studies were eligible to be included in this analysis. In the linear dose-response analysis (Fig. 2), the summary RR for every $300 \mathrm{mg} / \mathrm{d}$ increase in Ca intake was 0.98 (95\% CI 0.96, 0.99, $\left.P_{\text {heterogeneity }}=0 \cdot 123, I^{2}=30 \cdot 8 \%\right)$ for all women, without evidence of a non-linear relationship $\left(P_{\text {non-linearity }}=0 \cdot 17\right)$, although the reduction in breast cancer risk appeared somewhat steeper in the lower range of $\mathrm{Ca}$ intake $(<800 \mathrm{mg} / \mathrm{d})$ than in the higher range (online Supplementary Fig. S2). By menopausal status (Fig. 2), the summary RR were 0.92 (95\% CI 0.87, 0.98) for premenopausal breast cancer and 0.98 (95\% CI 0.97, 0.99) for postmenopausal breast cancer. By sources of $\mathrm{Ca}$, the summary RR were 0.97 (95\% CI 0.95, 0.98) for dietary Ca and 0.99 (95\% CI 0.97, 1.01) for supplemental Ca (online Supplementary Fig. S3).

\section{Discussion}

The present meta-analysis of eleven prospective studies supports an inverse association between $\mathrm{Ca}$ intake and breast cancer. Dose-response analysis revealed that each $300 \mathrm{mg} / \mathrm{d}$ increase in Ca intake was significantly associated with 2, 8 and $2 \%$ reduced risk of total, premenopausal and postmenopausal breast cancer, respectively.

Although the exact mechanisms by which Ca may reduce the risk of breast cancer remain unclear, the ability of $\mathrm{Ca}$ in regulating cell proliferation, differentiation and apoptosis makes it biologically plausible as a potential protective factor against breast cancer ${ }^{(5-7)}$. Evidence from animal studies suggests that $\mathrm{Ca}$ has anti-proliferative and pro-differentiation actions on mammary gland cells of rats fed the high-fat diet, and can reduce the incidence of mammary tumours in rats ${ }^{(8,9)}$. Much of the evidence indicates that the anti-carcinogenic potential of Ca relies on its interrelation and correlation with vitamin D. However, experimental evidence suggests that an increased level of $\mathrm{Ca}$ alone is sufficient to trigger apoptosis ${ }^{(10)}$. Increased risk of breast cancer has been linked with several chronic diseases such as diabetes, obesity and the metabolic syndrome ${ }^{(38-41)}$, all of which have been suggested to be inversely associated with $\mathrm{Ca}$ intake ${ }^{(42-44)}$. Therefore, Ca intake may indirectly be associated with lower breast cancer risk through its association with these disorders.

With additional five large prospective studies ${ }^{(15-19)}$ included and comprehensive analyses conducted, our findings are generally consistent with those from the previous meta-analysis ${ }^{(14)}$, and thereby further support a potentially beneficial role of $\mathrm{Ca}$ in the development of breast cancer. Indeed, a possible U-shaped association between $\mathrm{Ca}$ intake and health outcomes has been widely considered ${ }^{(45,46)}$ Numerous studies also suggested that a high intake of $\mathrm{Ca}$, particularly from supplements, may be associated with increased risks of $\mathrm{CVD}^{(19-23)}$ and kidney stones ${ }^{(24,25)}$. Given concerns about adverse risks of ingesting a high dose of $\mathrm{Ca}$ on health, the maximum daily $\mathrm{Ca}$ intake from 


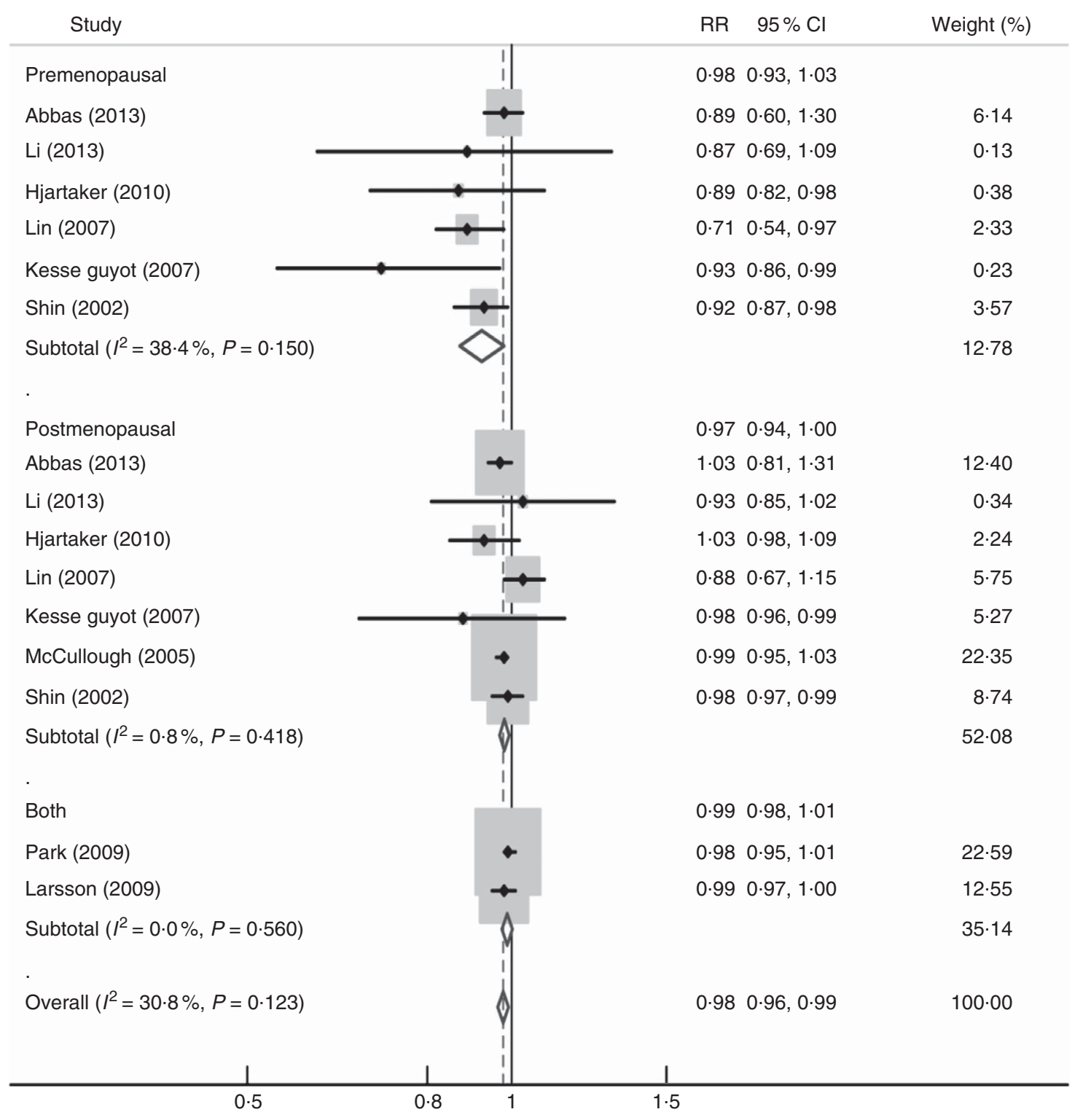

Fig. 2. Dose-response meta-analysis of calcium intake (per $300 \mathrm{mg} / \mathrm{d}$ ) and breast cancer risk. RR, relative risks.

diet and/or dietary supplement should be carefully considered $^{(47)}$. Results of our dose-response analysis showed that the inverse association of $\mathrm{Ca}$ intake with breast cancer risk remained when the intake was up to $1900 \mathrm{mg} / \mathrm{d}$.

The inverse relation between $\mathrm{Ca}$ intake and breast cancer appeared to be stronger in the dietary Ca group (RR 0.90; $95 \%$ CI $0.84,0.97 ; n$ ) than in the supplemental Ca group (RR 0.98; $95 \%$ CI $0.92,1.03 ; n$ 6). There were several explanations for these findings. First, it is possible that the interactions between $\mathrm{Ca}$ and other nutrient components in diets, such as vitamin D, conjugated linoleic acids and SFA, are necessary for Ca to exert its protection on breast cancer ${ }^{(48)}$. Second, it is possible that the benefits of $\mathrm{Ca}$ may be restricted to the individuals with $\mathrm{Ca}$ deficiencies, and Ca supplementation may not bring additional benefits for those who have consumed enough Ca from foods. Third, it is also possible that the observed inverse association may be partly or completely explained by other beneficial nutrients (potential confounders) that share similar food sources with $\mathrm{Ca}$.

Furthermore, the findings from our meta-analysis were consistent with previous meta-analysis showing that inverse association of $\mathrm{Ca}$ intake with breast cancer risk is limited to premenopausal women ${ }^{(14)}$. To date, convincing explanations for the menopause-related difference in the association of $\mathrm{Ca}$ intake with the risk of breast cancer have not yet been established. We considered several possible explanations for this difference. First, the complex interactions among $\mathrm{Ca}$, vitamin $\mathrm{D}$ and insulin-like growth factors may promote growth inhibition in breast cancer cells ${ }^{(13,49)}$. Second, Ca may serve as a potential regulator in oestrogen-driven cell proliferation ${ }^{(50)}$. Third, as $\mathrm{Ca}$ inadequacy is more prominent in postmenopausal women ${ }^{(51,52)}$, it is also possible that the beneficial effects of $\mathrm{Ca}$ in postmenopausal women might only occur in higher doses. 


\section{Strengths and limitations}

The present study has several strengths, including incorporated evidence and relevant studies to the date. The enlarged sample size enhanced the power to detect a significant difference and provide more precise estimates of the effects. Most of the original studies included are of long follow-up durations, and all studies used a prospective design, which thereby reduced the likelihood of potential biases (e.g. recall and selection biases). We quantified the association between intake of $\mathrm{Ca}$ and risk of breast cancer by carrying out linear and non-linear dose-response analyses. Given the considerably distinct levels of the intake among different populations, a dose-response meta-analysis is necessary in addition to the comparison of the highest $v$. lowest categories of intake.

There are several potential limitations that are worthy of consideration in this meta-analysis. First, there was evidence of publication bias. Although the results did not change after using statistical methods to correct the bias, findings based on evidence of published data should always be interpreted with caution. Second, the strong interrelationship between Ca intake and vitamin D intake makes it difficult to identify the true effects of $\mathrm{Ca}$ intake on breast cancer risk as an independent variable in observational studies. Third, the present meta-analysis was unable to assess breast cancer subtypes by hormone receptor status because of the limited studies available. In clinical course of breast cancer, hormonal status is very important for predicting prognosis and efficacy of chemotherapy; thereby, it may also be important to assess whether $\mathrm{Ca}$ intake and risk of breast cancer is modified by ER/PR status of the tumour. Fourth, there was moderate heterogeneity across studies. The heterogeneity may be because of the variation in exposure definitions, exposure ranges, dietary assessment methods or population characteristics among studies. Our further analyses indicated that menopausal status was a major potential contributor to the variation in the strength of the association. Finally, although individual studies have considered a wide range of potential confounders in their analyses, the potential impacts of residual/unknown confounding factors on our findings cannot be completely excluded.

\section{Conclusion}

In summary, results from this meta-analysis of eleven prospective cohort studies suggest an inverse dose-response association between $\mathrm{Ca}$ intake and breast cancer. Additional large prospective studies focusing on the influence of hormone receptor status on this association are necessary to confirm our findings, and such studies would also be helpful for exploring potential mechanisms whereby $\mathrm{Ca}$ may reduce breast cancer.

\section{Acknowledgements}

This research received no specific grant from any funding agency, commercial or not-for-profit sectors.

K. H. and G.-C. C. contributed to the study design, literature search, data extraction and data analyses. K. H. wrote the paper. R. Z. assisted with literature selection. R. Z., X. D. and S.-Y. Z. provided statistical support and created all tables and figures.
L.-Q. Q. and B.-M. S. critically reviewed the manuscript for important intellectual content. All authors read and approved the final manuscript.

There are no conflicts of interest.

\section{Supplementary material}

For supplementary material/s referred to in this article, please visit http://dx.doi.org/10.1017/S0007114516001768

\section{References}

1. Global Burden of Disease Cancer Collaboration, Fitzmaurice C, Dicker D, et al. (2015) The global burden of cancer 2013. JAMA Oncol 1, 505-527.

2. Gerber B, Müller H, Reimer T, et al. (2003) Nutrition and lifestyle factors on the risk of developing breast cancer. Breast Cancer Res Treat 79, 265-276.

3. Catsburg C, Kim RS, Kirsh VA, et al. (2015) Dietary patterns and breast cancer risk: a study in 2 cohorts. Am J Clin Nutr 101, 817-823.

4. Singletary KW \& Gapstur SM (2001) Alcohol and breast cancer: review of epidemiologic and experimental evidence and potential mechanisms. JAMA 286, 2143-2151.

5. Whitfield JF, Boynton AL, MacManus JP, et al. (1979) The regulation of cell proliferation by calcium and cyclic AMP. Mol Cell Biochem 27, 155-179.

6. Mathiasen IS, Sergeev IN, Bastholm L, et al. (2002) Calcium and calpain as key mediators of apoptosis-like death induced by vitamin D compounds in breast cancer cells. J Biol Chem 277, 30738-30745.

7. Sergeev IN (2004) Calcium as a mediator of 1,25-dihydroxyvitamin $\mathrm{D}_{3}$-induced apoptosis. I Steroid BiochemMolBiol 89-90, 419-425.

8. Jacobson EA, James KA, Newmark HL, et al. (1989) Effects of dietary fat, calcium, and vitamin $\mathrm{D}$ on growth and mammary tumorigenesis induced by 7,12-dimethylbenz(a)anthracene in female Sprague-Dawley rats. Cancer Res 49, 6300-6303.

9. Abou-Issa H, Moeschberger M, el-Masry W, et al. (1995) Relative efficacy of glucarate on the initiation and promotion phases of rat mammary carcinogenesis. Anticancer Res 15 , 805-810.

10. Kumar B, Kumar A, Ghosh S, et al. (2012) Diospyrin derivative, an anticancer quinonoid, regulates apoptosis at endoplasmic reticulum as well as mitochondria by modulating cytosolic calcium in human breast carcinoma cells. Biochem Biophys Res Commun 417, 903-909.

11. Knekt $\mathrm{P}$, Järvinen $\mathrm{R}$, Seppänen $\mathrm{R}$, et al. (1996) Intake of dairy products and the risk of breast cancer. Br J Cancer $\mathbf{7 3}$, 687-691.

12. Kesse-Guyot E, Bertrais S, Duperray B, et al. (2007) Dairy products, calcium and the risk of breast cancer: results of the French SU.VI.MAX prospective study. Ann Nutr Metab 51, $139-145$.

13. Lin J, Manson JE, Lee IM, et al. (2007) Intakes of calcium and vitamin D and breast cancer risk in women. Arch Intern Med 167, 1050-1059.

14. Chen P, Hu P, Xie D, et al. (2010) Meta-analysis of vitamin D, calcium and the prevention of breast cancer. Breast Cancer Res Treat 121, 469-477.

15. Park Y, Leitzmann MF, Subar AF, et al. (2009) Dairy food, calcium, and risk of cancer in the NIH-AARP Diet and health study. Arch Intern Med 169, 391-401. 
16. Hjartåker A, Thoresen M, Engeset D, et al. (2010) Dairy consumption and calcium intake and risk of breast cancer in a prospective cohort: the norwegian women and cancer study. Cancer Causes Control 21, 1875-1885.

17. Li J, Koh WP, Jin AZ, et al. (2013) Calcium intake is not related to breast cancer risk among Singapore Chinese women. Int J Cancer 133, 680-686.

18. Genkinger JM, Makambi KH, Palmer JR, et al. (2013) Consumption of dairy and meat in relation to breast cancer risk in the black women's health study. Cancer Causes Control 24, 675-684.

19. Abbas S, Linseisen J, Rohrmann S, et al. (2013) Dietary intake of vitamin D and calcium and breast cancer risk in the European prospective investigation into cancer and nutrition. Nutr Cancer 65, 178-187.

20. Xiao Q, Murphy RA, Houston DK, et al. (2013) Dietary and supplemental calcium intake and cardiovascular disease mortality: the National Institutes of Health-AARP Diet and Health Study. JAMA Intern Med 173, 639-646.

21. Bolland MJ, Grey A, Avenell A, et al. (2011) Calcium supplements with or without vitamin D and risk of cardiovascular events: reanalysis of the Women's Health Initiative limited access dataset and meta-analysis. BMJ 342, d2040.

22. Bolland MJ, Barber PA, Doughty RN, et al. (2008) Vascular events in healthy older women receiving calcium supplementation: randomised controlled trial. BMJ 336, 262-266.

23. Li K, Kaaks R, Linseisen J, et al. (2012) Associations of dietary calcium intake and calcium supplementation with myocardial infarction and stroke risk and overall cardiovascular mortality in the Heidelberg cohort of the European prospective investigation into Cancer and Nutrition study (EPIC-Heidelberg). Heart 8, 920-925.

24. Pentti K, Tuppurainen MT, Honkanen R, et al. (2009) Use of calcium supplements and the risk of coronary heart disease in 52-62-year-old women: the kuopio osteoporosis risk factor and prevention study. Maturitas 63, 73-78.

25. Jackson RD, LaCroix AZ, Gass M, et al. (2006) Calcium plus vitamin D supplementation and the risk of fractures. $N$ Engl J Med 354, 669-683.

26. Curhan GC, Willett WC, Speizer FE, et al. (1997) Comparison of dietary calcium with supplemental calcium and other nutrients as factors affecting the risk for kidney stones in women. Ann Intern Med 126, 497-504.

27. Moher D, Liberati A, Tetzlaff J, et al. (2009) Preferred reporting items for systematic reviews and meta-analyses: the PRISMA statement. PLoS Med 6, e1000097.

28. Wells GA, Shea B, O'Connell D, et al. (2000) The NewcastleOttawa Scale (NOS) for assessing the quality of nonrandomized studies in meta-analyses. http://www.ohri.ca/programs/ clinical_epidemiology/oxford.asp (accessed March 2016).

29. DerSimonian R \& Laird N (1986) Meta-analysis in clinical trials. Control Clin Trials 7, 177-188.

30. Egger M, Davey Smith G, Schneider M, et al. (1997) Bias in meta-analysis detected by a simple, graphical test. BMJ $\mathbf{3 1 5}$, 629-634.

31. Duval S \& Tweedie R (2000) Trim and fill: a simple funnelplot-based method of testing and adjusting for publication bias in meta-analysis. Biometrics 56, 455-463.

32. Greenland S \& Longnecker MP (1992) Methods for trend estimation from summarized dose-response data, with applications to meta-analysis. Am J Epidemiol 135, 1301-1309.

33. Orsini N, Bellocco R \& Greenland S (2006) Generalized least squares for trend estimation of summarized doseresponse data. Stata J 6, 40-57.

34. Orsini N, Li R, Wolk A, et al. (2012) Meta-analysis for linear and nonlinear dose-response relations: examples, an evaluation of approximations, and software. Am J Epidemiol 175, 66-73.

35. Shin MH, Holmes MD, Hankinson SE, et al. (2002) Intake of dairy products, calcium, and vitamin $\mathrm{d}$ and risk of breast cancer. J Natl Cancer Inst 94, 1301-1311.

36. McCullough ML, Rodriguez C, Diver WR, et al. (2005) Dairy, calcium, and vitamin D intake and postmenopausal breast cancer risk in the cancer prevention Study II nutrition cohort. Cancer Epidemiol Biomarkers Prev 14, 2898-2904.

37. Larsson SC, Bergkvist L \& Wolk A (2009) Long-term dietary calcium intake and breast cancer risk in a prospective cohort of women. Am J Clin Nutr 89, 277-282.

38. Porto LA, Lora KJ, Soares JC, et al. (2011) Metabolic syndrome is an independent risk factor for breast cancer. Arch Gynecol Obstet 284, 1271-1276.

39. Lipscombe LL, Fischer HD, Austin PC, et al. (2015) The association between diabetes and breast cancer stage at diagnosis: a population-based study. Breast Cancer Res Treat 150, 613-620.

40. Harvie M, Howell A, Vierkant RA, et al. (2005) Association of gain and loss of weight before and after menopause with risk of post-menopausal breast cancer in the Iowa women's health study. Cancer Epidemiol Biomarkers Prev 14, 656-661.

41. Eliassen AH, Colditz GA, Rosner B, et al. (2006) Adult weight change and risk of post-menopausal breast cancer. JAMA 296, 193-201.

42. Moore-Schiltz L, Albert JM, Singer ME, et al. (2015) Dietary intake of calcium and magnesium and the metabolic syndrome in the National Health and Nutrition Examination (NHANES) 2001-2010 data. Br J Nutr 114, 924-935.

43. Pittas AG, Dawson-Hughes B, Li T, et al. (2006) Vitamin D and calcium intake in relation to type 2 diabetes in women. Diabetes Care 29, 650-656.

44. Lee HJ, Cho JI, Lee HS, et al. (2014) Intakes of dairy products and calcium and obesity in Korean adults: Korean National Health and Nutrition Examination Surveys (KNHANES) 2007-2009. PLOS ONE 9, e99085.

45. Larsson SC, Orsini N \& Wolk A (2013) Dietary calcium intake and risk of stroke: a dose-response meta-analysis. $\mathrm{Am} \mathrm{J}$ ClinNutr 97, 951-957.

46. Wang X, Chen H, Ouyang Y, et al. (2014) Dietary calcium intake and mortality risk from cardiovascular disease and all causes: a meta-analysis of prospective cohort studies. BMC Medicine 12, 158.

47. Committee to Review Dietary Reference Intakes for Vitamin D and Calcium, Food and Nutrition Board \& Institute of Medicine (2010) Dietary Reference Intakes for Calcium and Vitamin D. Washington, DC: National Academies Press.

48. Dong JY, Zhang L, He K, et al. (2011) Dairy consumption and risk of breast cancer: a meta-analysis of prospective cohort studies. Breast Cancer Res Treat 127, 23-31.

49. Allen NE, Roddam AW, Allen DS, et al. (2005) A prospective study of serum insulin-like growth factor-I (IGF-I), IGF-II, IGF-binding protein-3 and breast cancer risk. BrJ Cancer $\mathbf{9 2}$, $1283-1287$

50. Liu G, Hu X \& Chakrabarty S (2009) Calcium sensing receptor down-regulates malignant cell behavior and promotes chemosensitivity in human breast cancer cells. Cell Calcium 45, 216-225.

51. Malabanan AO \& Holick MF (2003) Vitamin D and bone health in postmenopausal women. $J$ Womens Health (Larchmt) 12, 151-156.

52. Meng X, Kerr DA, Zhu K, et al. (2010) Calcium intake in elderly Australian women is inadequate. Nutrients $\mathbf{2}$, 1036-1043. 